\title{
Keefektifan Model Pembelajaran Group Investigation Berbantu Media Puzzle Board Terhadap Hasil Belajar IPA
}

\author{
Astari Hanifah ${ }^{1 *}$, Mudzanatun², Sukamto ${ }^{3}$ (iD \\ 1,2,3 Program Studi Pendidikan Guru Sekolah Dasar, Universitas PGRI Semarang, Indonesia \\ *Corresponding author: hanifah@gmail.com
}

\begin{abstract}
Abstrak
Kurangnya inovasi dalam proses pembelajaran seperti rendahnya penggunaan model dan media yang mampu mengedepankan peran siswa secara aktif dalam pembelajaran, menyebabkan hasil belajar IPA siswa sekolah dasar cenderung rendah. Tujuan penelitian ini adalah untuk mengetahui keefektifan dari model pembelajaran group investigation berbantu media puzzle board terhadap hasil belajar IPA materi alat pencernaan manusia kelas V SD. Sehingga jenis penilitian yang digunakan adalah penelitian kuantitatif dengan model pre experimental design bentuk one group pretest-posttest. Populasi penelitian adalah siswa kelas $\mathrm{V}$ yang berjumlah 22 siswa. Penelitian ini menggunakan teknik sampling jenuh sehingga semua anggota populasi dijadikan sebagai sampel. Data dalam penelitian ini diperoleh melalui observasi, wawancara, dokumentasi dan tes. Teknik analisis data peneliti menggunakan uji normalitas awal, uji normalitas akhir, dan uji hipotesis (uji t). Berdasarkan hasil perhitungan dapat diketahui bahwa nilai rata-rata posttest $>$ pretest yaitu 72,5 $>60,5$. Diperkuat dengan hasil perhitungan hipotesis dengan menggunakan uji t diperoleh thitung $>$ tabel yaitu 6,723>2,080 pada taraf signifikansi 5\%, maka $\mathrm{H}_{\mathrm{a}}$ diterima. Dari hasil analisis tersebut dapat disimpulkan bahwa model pembelajaran group investigation efektif digunakan untuk meningkatkan hasil belajar IPA materi alat pencernaan manusia pada siswa kelas V SD.
\end{abstract}

Kata kunci: Group Investigation, Puzzle Board, Hasil Belajar IPA

\section{Abstract}

The problem in this study is the lack of learninginnovations such as the use of learning models and media that are able to promote the active role of students in learning, so that science learning outcomes tend to be low. The purpose of this study was to determine the effectiveness of the group investigation learning model assisted by the puzzle board media on the science learning outcome of the fifth grade human digestive apparatus at SDN Menur Demak. This type of research is quantitative with a pre-experimental design model in the form of the one group pretest-posttest. A total of 22 student in grade $V$ were the study population. All members of the population were sampled so that the saturated sampling technique was used. The data in this study were obtained through observation, interviews, documentation, and tests. Researchers data analysis technique used the initial normality test, the final normality test, and hypothesis testing ( $t$ test). Based on the results of the calculation, it can be seen that the average value of posttest > pretest is 72,5>60,5. Reinforced bt the results of the calculation of the hypothesis using the $t$ test, it is obtained tcount > ttable namely 6,7233>2.080 at the $5 \%$ significance level, then $H_{a}$ is accepted. From the results of the analysis, it was concluded that the group investigation learning model was effective on the science learning outcomes of the human digestive apparatus material in fifth grade of SDN Menur Demak.

Keywords: Group Investigation, Puzzle Board, Science Learning Outcome

\section{Introduction}

Pendidikan merupakan aspek terpenting dalam kemajuan suatu bangsa dan negara. Pendidikan berperan untuk menciptakan sumber daya manusia yang berkualitas dan berwawasan luas. Melalui pendidikan, akan terbentuk generasi penerus bangsa yang tidak hanya memiliki pengetahuan dan keterampilan, tetapi juga memiliki karakter diri yang mengarah pada pribadi yang lebih baik. Sebagaimana yang termuat dalam Undang-Undang Republik Indonesia No. 20 Tahun 2003 Tentang Sistem Pendidikan Nasional, bahwa

$\begin{array}{lll}\text { History: } & \text { Publisher: Undiksha Press } \\ \text { Received } & : 15 \text { August } 2020 & \text { Licensed: This work is licensed under } \\ \text { Revised } & : 15 \text { September } 2020 & \\ \text { Accepted } & : 20 \text { October } 2020 & \text { a Creative Commons Attribution 3.0 License } \\ \text { Published } & : 1 \text { Desember } 2020 & \end{array}$


"pendidikan adalah usaha sadar dan terencana untuk mewujudkan suasana belajar dan pembelajaran agar peserta didik mengembangkan potensi dirinya untuk memiliki kekuatan spiritual keagamaan, pengendalian diri, kepribadian, kecerdasan, akhlak mulia, serta keterampilan yang diperlukan dirinya, masyarakat, bangsa, dan negara." Berdasarkan kutipan Undang-Undang tersebut dapat diketahui bahwa pendidikan perlu dikembangkan dari masakemasa demi terwujudnya layanan pendidikan yang ideal bagi siswa. Indonesia sebagai salah satu negara berkembang terus berupaya meningkatkan mutu pendidikan guna mengikuti perkembangan zaman dan teknologi yang semakin maju. Peningkatan mutu pendidikan dapat dilakukan dengan melaksanakan proses pembelajaran yang berkualitas. Karena muara dari program pendidikan adalah terlaksananya program pembelajaran yang berkualitas dan tecapainya tujuan instruktusional.

Kualitas proses pembelajaran pada satuan pendidikan didukung dengan Peraturan Pemerintah Nomor 32 Tahun 2013 Tentang Standar Nasional Pendidikan bahwa, proses pembelajaran pada satuan pendidikan diselenggarakan secara interaktif, inspiratif, menantang, memotivasi peserta didik untuk berpartisipasi aktif serta memberikan ruang yang cukup bagi prakarsa, kreativitas, dan kemandirian sesuai dengan bakat, minat, dan perkembangan fisik serta psikologi peserta didik. Setiap proses pembelajaran diarahkan untuk mencapai tujuan yang telah ditetapkan. Guru berperan penting dalam keberhasilan pembelajaran, karena guru menjadi ujung tombak dalam menentukan dan mengarahkan segala kegiatan belajar mengajar. Tugas seorang guru bukan hanya sekedar mengajar atau mentransfer ilmu, tetapi juga mendidik dan membimbing siswa dengan memberikan fasilitas belajar untuk mengembangkan kemampuan dan potensinya, agar memiliki karakter yang baik dan juga soft skill (pengetahuan dan keterampilan) sebagai pendukungnya (Maya, 2013). Berdasarkan peran guru sebagai pengelola proses pembelajaran, guru harus mampu merencanakan sistem pembelajaran dengan maksimal, meliputi pengembangan silabus dan RPP yang memuat sekurang-kurangnya tujuan pembelajaran, materi ajar, metode pengajaran, sumber belajar dan penilaian hasil belajar untuk meningkatkan mutu belajar siswa. Selain itu guru juga harus mampu melaksanakan pembelajaran dengan baik meliputi pengelolaan kelas untuk menciptakan kondisi belajar yang optimal. Kondisi belajar yang optimal dapat tercapai apabila guru mampu mengatur siswa dan sarana pengajaran, serta mengendalikan pembelajaran dengan suasana yang menyenangkan. Oleh karena itu, sebagai penentu keberhasilan siswa guru dituntut untuk menciptakan dan mengembangkan inovasi pembelajaran yang berorientasi pada keaktifan siswa, dengan memperhatikan tujuan, keadaan, kebutuhan, dan karakter siswa. Suatu proses pembelajaran dikatakan berhasil apabila, terciptanya kondisi belajar yang optimal dengan adanya interaksi belajar antara guru dan siswa dengan suasana belajar menyenangkan, untuk mencapai tujuan pembelajaran (Wibowo, 2016).

Ketercapaian tujuan pembelajaran dapat dilihat dari hasil belajar melalui pengukuran. Menurut Susanto (2016), hasil belajar dapat diartikan sebagai tingkat keberhasilan siswa dalam mempelajari materi pelajaran di sekolah yang dinyatakan dalam bentuk skor yang diperoleh dari hasil tes mengenai sejumlah materi pelajaran tertentu. Pengukuran hasil belajar dapat dilakukan melalui evaluasi tes. Evaluasi dilakukan dengan tujuan untuk memperoleh data pembuktian, yang akan menjadi petunjuk sampai sejauh mana tingkat kemampuan dan keberhasilan siswa dalam pencapaian tujuan, serta menilai efektifitas pembelajaran yang telah dilaksanakan oleh guru.

IPA merupakan gabungan ilmu pengetahuan yang menjelaskan gejala fisik yang terjadi di alam semesta secara sistematis dan bukan hanya penguasaan pengetahuan berupa faktafakta, konsep-konsep atau prinsip-prinsip saja, tetapi merupakan suatu proses penemuan yang mengamati alam, cara IPA mengamati dunia ini bersifat analisis, cermat, serta menghubungkan antara satu fenomena dengan fenomena lain, sehingga keseluruhannya membentuk perspektif yang baru tentang objek yang diamatinya yang tersusun secara teratur, berlaku secara umum 
(universal) serta berupa kumpulan data hasil observasi dan eksperimen (Samatowa, 2011; Tias, 2017; Trianto, 2010). Pembelajaran IPA mencakup 3 aspek penting yaitu: 1) sebagai produk, yaitu kumpulan berupa fakta dan konsep hasil penelitian, 2) sebagai proses, yaitu proses menggali dan memahami tentang alam melaui kegiatan mengamati, mengukur, mengklasifikasi, dan menyimpulkan, 3) sebagai sikap, yaitu sikap yang dimiliki dalam melakukan dan mengkomunikasikan hasil penelitiannya Pembelajaran IPA di sekolah dasar tidak hanya bersifat verbal atau hafalan saja, tetapi juga merupakan pengetahuan faktual dengan melakukan kegiatan pengamatan atau percobaan, agar siswa mampu menggali pengetahuannya sendiri melalui pengalamannya. Trianto, (2010) Pembelajaran IPA harus menekankan pada pengalaman langsung untuk mengembangkan kompetensi agar peserta didik mampu memahami alam sekitar melalui kegiatan "mencari tahu" atau "berbuat", hal ini akan membantu peserta didik memperoleh pengetahun yang lebih mendalam. Oleh karena itu, dalam pembelajaran IPA guru berperan sebagai fasilitator serta motivator dan siswa dituntut untuk aktif dalam pembelajaran dengan menekankan pada pemberian pengalaman belajar secara langsung melalui keterampilan proses sehingga menumbuhkan sikap ilmiah siswa (Azizah, 2018; Ernawati M, 2018). Pembelajaran IPA yang mampu melibatkan siswa secara aktif melalui pengalaman belajarnya akan mampu mendapat hasil belajar yang maksimal.

Berdasarkan hasil observasi awal dan wawancara dengan guru kelas V di SDN Menur Demak, didpatkan informasi bahwa pelaksanaan pembelajaran memang berlangsung sudah cukup baik, tetapi masih belum efektif. Pembelajaran yang dilakukan memiliki kecenderungan menggunakan metode konvensional seperti ceramah, tanya jawab, dan pemberian tugas secara individu. Selain itu minimnya penggunaan media pembelajaran sebagai sarana penunjang pemahaman konsep materi oleh siswa. Kegiatan pembelajaran seperti ini terkesan monoton dan kurang bermakna bagi siswa, karena belum sepenuhnya mengedepankan keterlibatan siswa secara aktif, sehingga kondisi pembelajaran menjadi tidak kondusif. Pembelajaran IPA selama ini dianggap sulit bagi siswa karena banyaknya materi yang harus dipelajari dan dipahami, salah satunya materi alat pencernaan manusia. Pada kenyataannya banyak siswa yang mengalami kesulitan dalam mempelajari materi ini. Hal ini terbukti dari hasil ulangan harian IPA ke-3 yang didapatkan siswa cenderung rendah. Dari 20 siswa, terdapat 14 siswa (70\%) yang belum memenuhi KKM, dan 6 siswa (30\%) yang sudah memenuhi KKM, mengingat Kriteria Ketuntasan Minimal (KKM) yang ditentukan sekolah pada mata pelajaran IPA yaitu 70. Berdasarkan permasalahan yang dipaparkan, untuk mencapai keberhasilan dalam mengoptimalkan kompetensi pengetahuan IPA siswa, perlu adanya inovasi pembelajaran dengan menggunakan model pembelajaran bervariasi dan media yang merangsang minat siswa untuk lebih antusias serta berperan aktif dalam proses pembelajaran. Pembelajaran yang sebelumnya berpusat pada guru (teaching center) diarahkan menuju pembelajaran yang berpusat pada siswa (student center). Salah satu model pembelajaran yang efektif dan efisien sesuai dengan karakteristik pembelajaran IPA dalam kegiatan observasi atau pengamatan adalah model group investigation.

Model pembelajaran group investigation merupakan suatu pola pembelajaran yang memberikan kebebasan siswa untuk mengembangkan cara berfikir dan meningkatkan kemampuannya dengan menggali sumber belajar melalui kegiatan investigasi kelompok (Mushoddik et al., 2016; Suputra et al., 2013). Menurut Rusman (2017) strategi belajar koopratif group investigation sangat ideal diterapkan dalam pembelajaran biologi (IPA) hal ini dikarenakan topik pembelajaran IPA cukup luas dan sub bab topik yang mengarah pada kegiatan ilmiah. Selanjutnya dalam tahap investigasi siswa diarahkan untuk mencari tahu dari berbagai macam sumber. Siswa kemudian melakukan evaluasi dan sintesis terhadap informasi yang dihadapatkannya dalam upaya untuk membuat laporan ilmiah sebagai hasil kelompok.

Penerapan model pembelajaran group investigation tentunya tidak lepas dari penggunaan media sebagai alat bantu dalam penyampaian materi pelajaran. Media adalah komponen 
sumber belajar yang mengandung materi instruktusional di lingkungan siswa yang dapat merangsang siswa untuk belajar (Hayes et al., 2017; Mahnun, 2012). Agar media dapat tersampaikan dan mampu memberikan pengalaman belajar langsung kepada siswa, maka dalam memilih media pembelajaran harus disesuaikan dengan karakteristik kebutuhan dan kondisi siswa. Adapun karakteristik pemilihan media menurut (Sudjana \& Rivai, 2010) adalah: 1) ketepatannya dengan tujuan pembelajaran 2) dukungan terhadap isi pelajaran 3) kemudahan dalam memperoleh media 4) keterampilan guru dalam menggunakannya 5) tersedia waktu untuk menggunakannya 6) sesuai dengan taraf berpikir siswa. Pembelajaran IPA yang erat kaitannya dengan lingkungan alam tidak mungkin dihadirkan didalam kelas, maka sangat penting menggunakan media yang fleksibel namun dapat memberikan gambaran pada siswa dalam kegiatan pembelajaran. Media yang digunakan sebagai pertimbangan dalam implementasi model pembelajaran group investigation adalah media puzzle board.

Media puzzle board merupakan media edukasi dua dimensi beralas papan dengan berbahan lembaran logam yang dapat menarik benda dengan daya magnet. Benda tersebut berupa potongan-potongan puzzle dengan bentuk alat pencernaan manusia yang dapat menempel atau merekat pada papan. Potongan-potongan puzzle dibuat menggunakan sterofom yang dilapisi kertas tebal berwarna-warni. Potongan puzzle dapat disusun atau ditempelkan pada papan dan membentuk keseluruhan secara utuh. Media puzzle board berfungsi sebagai alat bantu dalam memahami konsep pada materi alat pencernaan manusia secara berurutan (Dara Asshofi et al., 2019). Media ini memiliki daya tarik tersendiri, karena siswa dapat melihat secara langsung dan dengan leluasa memanipulasinya sesuai dengan materi pembelajaran. Melalui media puzzle board dapat meningkatkan antusias belajar dan kreativitas siswa. Model pembelajaran group investigation berbantu media puzzle board bisa memberi stimulasi belajar kepada siswa untuk aktif dalam kegiatan pembelajaran, sehingga dapat menciptakan pembelajaran yang efektif dalam situasi yang kondusif dan mampu meningkatkan hasil belajar siswa khususnya pada mata pelajaran IPA.

Penelitian yang dilakukan oleh Wahyuni (2014) menunjukkan bahwa penerapan model pembelajaran GI (group investigation) dapat meningkatkan keaktifan serta hasil belajar IPS siswa kelas VI SD. Penelitian yang dilakukan oleh Purnamasari et al., (2018) menunjukkan bahwa penggunaan model pembelajaran GI (group investigation) dapat meningkatkan aktivitas guru dan siswa kelas pada VIII G SMP Negeri 1 Banjarmasin. Penelitian yang dilakukan oleh Sulistiodiono (2017) mampu meningkatkan prestasi belajar IPA pada siswa kelas V. Tujuan penelitian yaitu untuk mengetahui keefektifan dari model pembelajaran group investigation berbantu media puzzle board terhadap hasil belajar IPA materi alat pencernaan manusia kelas V SD. Penggunaan model pembelajaran group investigation berbantu media puzzle board diharapkan dapat meningkatkan hasil belajar IPA siswa kelas V.

\section{Materials and Methods}

Penelitian ini bertujuan untuk mengetahui keefektifan dari model pembelajaran group investigation berbantu media puzzle board terhadap hasil belajar IPA materi alat pencernaan manusia kelas V SD, sehingga jenis penelitian yang digunakan adalah penelitian kuantitatif dengan pendekatan eksperimen. Desain dari penelitian ini adalah pre experimental design dengan bentuk one group pretest posttest design. Variabel dari penelitian ini meliputi variabel bebas dan variabel terikat. Adapun variabel bebasnya adalah model pembelajaran group investigation berbantu media puzzle board, dan variabel terikatnya adalah hasil belajar IPA. Metode penelitian pada dasarnya merupakan cara ilmiah untuk mendapatkan data dengan tujuan dan kegunaan tertentu. Penelitian ini merupakan. Sugiyono (2016) desain pre experimental design dengan bentuk one group pretest posttest design terdapat tes awal atau pretest sebelum diberikan perlakuan. Dengan demikian hasil perlakuan dapat diketahui lebih akurat, karena dapat membandingkan dengan keadaan sebelum diberi perlakuan. Adapun tahap 
pelaksanaan desain penelitian adalah sebagai berikut: 1) Melakukan tes awal (pretest) untuk mengetahui skor rata-rata sebelum subyek mendapatkan pembelajaran dengan menggunakan model group investigation berbantu media puzzle board 2) memberikan perlakuan X yaitu perlakuan dengan menggunakan model group investigation berbantu media puzzle board 3) melakukan tes akhir (posttest) untuk mengetahui skor rata-rata setelah subyek mendapatkan pembelajaran dengan menggunakan model group investigation berbantu media puzzle board.

Populasi dari penelitian ini adalah seluruh siswa kelas V SDN Menur Demak berjumlah 22 siswa yang terdiri dari 13 siswa laki-laki dan 9 siswa perempuan. Teknik untuk pengambilan sampel yaitu menggunakan teknik Non Probability Sampling. Non Probability Sampling adalah teknik pengambilan sampel yang tidak memberikan peluang sama bagi setiap anggota populasi untuk dipilih menjadi sampel (Sugiyono, 2016). Semua anggota populasi digunakan sebagai sampel, sehingga jenis teknik sampling yang digunakan adalah sampling jenuh.

Teknik pengumpulan data yang digunakan dalam penelitian ini yaitu observasi, wawancara, dokumentasi dan tes. Observasi dilakukan melalui pengamatan pembelajaran IPA di kelas $\mathrm{V}$, untuk mengetahui permasalahan awal dalam pembelajaran. Wawancara dilakukan dengan guru kelas V sebagai narasumber, untuk mengetahui gambaran permasalahan yang ada pada obyek dengan lebih detail. Dokumentasi digunakan sebagai bukti otentik saat melakukan penelitian yang berupa daftar nama siswa, daftar nilai siswa dan foto yang menggambarkan aktivitas saat kegiatan penelitian berlangsung. Tes digunakan untuk memperoleh data hasil belajar siswa.

Teknik analisis data merupakan cara yang digunakan untuk mengolah data hasil penelitian guna memperoleh suatu kesimpulan. Adapun teknik analisis data yang digunakan adalah uji normalitas awal (pretest), uji normalitas akhir (posttest), dan uji hipotesis berupa uji t. Uji normalitas data merupakan uji prasyarat tentang kelayakan sebuah data untuk mengetahui apakah data tersebut berdistribusi normal atau tidak. Teknik yang digunakan untuk uji normalitas adalah liliefors. Adapun kriteria pengujiannya adalah jika $\mathrm{L}_{0}$ kurang dari nilai tabel liliefors maka sampel berasal dari populasi yang berdistribusi normal dan jika $\mathrm{L}_{0}$ lebih dari nilai tabel liliefors maka sampel berasal dari populasi yang berdistribusi tidak normal, dengan taraf signifikansi 5\%. Data yang telah lolos prasyarat kemudian dianalisis menggunakan uji hipotesis berupa uji $\mathrm{t}$ dengan rumus separated varians. Kriteria pengujiannya adalah $\mathrm{H}_{0}$ diterima jika $t_{\text {hitung }}<t_{\text {tabel }}$ dan $\mathrm{H}_{\mathrm{a}}$ diterima jika $t_{\text {hitung }}>\mathrm{t}_{\text {tabel. }}$. Pengujian dilakukan pada taraf signifikansi $5 \%$ dengan d.b=N-1. Untuk mengukur efektifitas tingkat keberhasilan suatu proses pembelajaran menggunakan kriteria ketuntasan belajar yang mengacu pada hasil belajar IPA siswa. Hasil belajar dikatakan efektif jika skor rata-rata lebih atau sama dengan KKM yaitu 70 dan terjadi ketuntasan belajar secara klasikal mencapai $80 \%$.

\section{Results and Discussion}

\section{Hasil Penelitian}

Pengambilan data nilai hasil belajar siswa dilakukan di kelas V SDN Menur Demak yang terdiri dari satu kelas dengan jumlah 22 siswa. Data hasil belajar diambil dari nilai pretest dan posttest untuk mengetahui kemampuan siswa pada mata pelajaran IPA materi alat pencernaan manusia. Pretest merupakan data awal yang diperoleh sebelum siswa diberi perlakuan dengan menggunakan model pembelajaran group investigation berbantu media puzzle board. Posttest merupakan data akhir yang diperoleh setelah diberikannya perlakuan dengan menggunakan model pembelajaran group investigation berbantu media puzzle board. Hasil nilai pretest dan posttest siswa diolah dan diperoleh nilai, yang disajikan pada tabel 1. 
Tabel 1. Nilai Pretest dan Posttest

\begin{tabular}{lcc}
\hline \multicolumn{1}{c}{ Kriteria } & \multicolumn{2}{c}{ Hasil Belajar } \\
\cline { 2 - 3 } & Pretest & Posttetst \\
\hline Jumlah peserta didik & 22 & 22 \\
Tuntas & 5 & 19 \\
Tidak tuntas & 17 & 3 \\
Rata - rata & 60,5 & 72,5 \\
\hline
\end{tabular}

Berdasarkan Tabel 1 dapat diketahui hasil belajar IPA siswa kelas V SDN Menur Demak dengan menggunakan model pembelajaran group investigation berbantu media puzzle board diperoleh nilai rata-rata pretest sebesar 60,5 dengan nilai tertinggi 80 dan nilai terendah 40 , dari 22 siswa hanya 5 siswa yang mencapai KKM dan 17 siswa belum mencapai KKM. Mengingat KKM IPA yang ditentukan sekolah yaitu 70. Sedangkan nilai rata-rata posttest diperoleh sebesar 72,5 dengan nilai tertinggi 90 dan terendah 50, dari 22 siswa hanya 3 siswa yang belum mencapai KKM dan 19 sudah mencapai KKM. Data pretest dan posttest dapat di gambarkan pada Gambar 1.

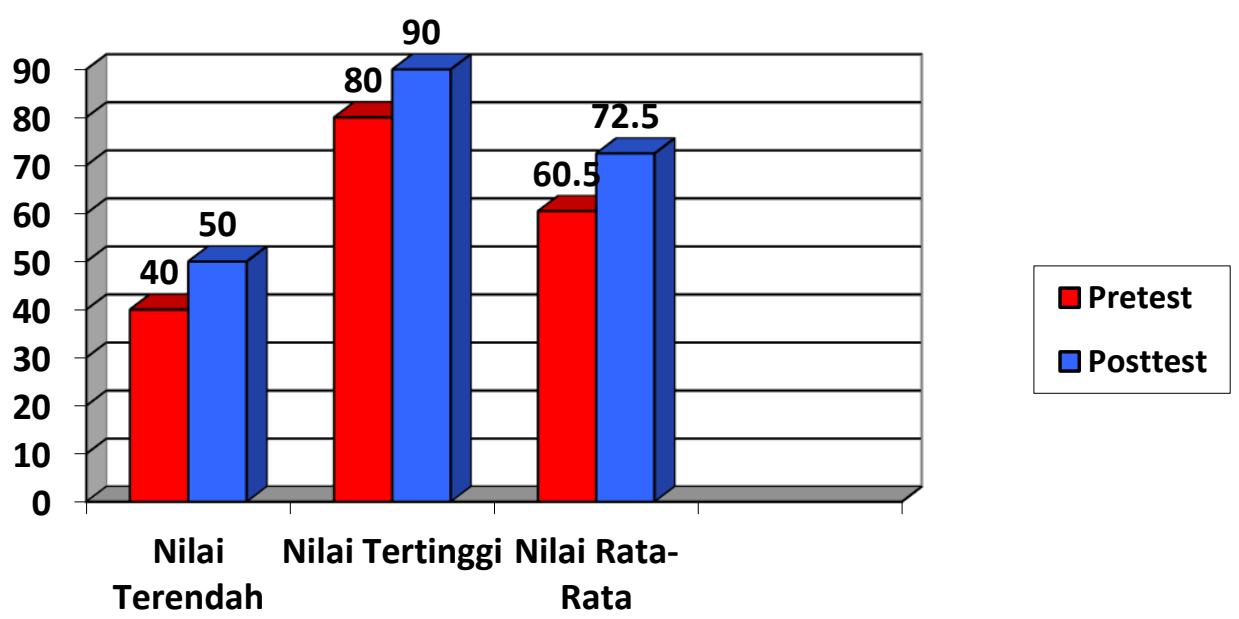

Gambar 1. Nilai Terendah, Nilai Tertinggi, dan Nilai Rata-Rata Pretest-Posttest

Berdasarkan gambar 1 dapat diketahui bahwa nilai rata-rata posttest setelah diberikan perlakuan dengan model group investigation dan media puzzle board lebih besar dari nilai rata-rata pretest sebelum diberikan perlakuan dengan model group investigation dan media puzzle board. Nilai rata-rata yang semula 60,5 meningkat menjadi 72,5. Hal ini menujukkan bahwa terdapat peningkatan hasil belajar yang didapatkan siswa sebesar $12 \%$.

Pada penelitian ini teknik analisis data yang digunakan adalah uji normalitas awal (pretest), uji normalitas akhir (posttest), dan uji hipotesis berupa uji t. Uji normalitas data merupakan uji prasyarat tentang kelayakan sebuah data untuk mengetahui apakah data tersebut berdistribusi normal atau tidak. Uji prasyarat terdiri dari analisis data awal pretest dan analisis data akhir posttest. Pengujian normalitas menggunakan uji liliefors dengan taraf signifikansi $5 \%$ atau 0,05 . Setelah data diketahui berdistribusi normal kemudian dianalisis hipotesisnya menggunakan uji t.

Uji normalitas awal digunakan untuk mengetahui apakah nilai pretest berasal dari sampel yang berdistribusi normal atau tidak. Uji normalitas menggunakan rumus Liliefors dengan 
ketentuan bahwa kelompok berdistribusi normal jika memenuhi kriteria $\mathrm{L}_{0}<\mathrm{L}_{\text {tabel }}$ yang diukur pada taraf signifikansi $5 \%$ atau 0,05 . Berdasarkan hasil perhitungan nilai pretest dengan $\mathrm{n}$ sebesar 22, diperoleh nilai $\mathrm{L}_{0}$ sebesar 0,1041 dan taraf signifikansi 5\% atau 0,05 diperoleh $\mathrm{L}_{\text {tabel }}$ sebesar 0,1889. Karena $\mathrm{L}_{0}<\mathrm{L}_{\text {tabel }}$ yaitu $0,1041<0,1889$ maka $\mathrm{H}_{\mathrm{a}}$ diterima. Artinya dapat disimpulkan bahwa sampel berasal dari populasi yang berdistribusi normal.

Uji normalitas akhir digunakan untuk mengetahui apakah nilai posttest berasal dari sampel yang berdistribusi normal atau tidak. Uji normalitas menggunakan rumus Liliefors dengan ketentuan bahwa kelompok berdistribusi normal jika memenuhi kriteria $\mathrm{L}_{0}<\mathrm{L}_{\text {tabel }}$ yang diukur pada taraf signifikansi $5 \%$ atau 0,05 . Berdasarkan hasil perhitungan nilai posttest dengan $\mathrm{n}$ sebesar 22, diperoleh nilai $\mathrm{L}_{0}$ sebesar 0,1586 dan taraf signifikansi $5 \%$ atau 0,05 diperoleh $\mathrm{L}_{\text {tabel }}$ sebesar 0,1889. Karena $\mathrm{L}_{0}<\mathrm{L}_{\text {tabel }}$ yaitu $0,1586<0,1889$ maka $\mathrm{H}_{\mathrm{a}}$ diterima. Artinya dapat disimpulkan bahwa sampel berasal dari populasi yang berdistribusi normal.

Setelah melakukan pengujian prasyarat analisis data dan diketahui bahwa data tersebut berdistribusi normal, maka langkah selanjutnya adalah melakukan pengujian hipotesis. Uji hipotesis dalam penelitian ini dihitung dengan menggunakan teknik uji-t yang digunakan untuk menguji apakah ada peningkatan hasil belajar siswa setelah dilakukan perlakuan yang dilihat berdasarkan nilai pretest dan posttest. Perhitungan menggunakan uji-T menunjukkan bahwa setelah menerapkan model pembelajaran group investigation berbantu media puzzle board terdapat perbedaan yang signifikan pada hasil belajar siswa kelas V pada mata pelajaran IPA alat pencernaan manusia dalam kegiatan belajar mengajar. Hal tersebut telah dibuktikan dengan pengujian hipotesis, yang menyatakan bahwa nilai thitung sebesar 6,723 dengan distribusi uji $\mathrm{t}$ diperoleh $\mathrm{d} \cdot \mathrm{b}=(\mathrm{n}-1)=(22-1)=21$ dengan taraf signifikansi $5 \%$ atau 0,05 didapatkan $t_{\text {tabel }}$ sebesar 2,080. Sehingga $t_{\text {hitung }}$ lebih besar dari nilai $t_{\text {tabel }}(6,723>2,080)$ yang artinya $\mathrm{Ha}$ diterima dan $\mathrm{H}_{0}$ ditolak. Perhitungan tersebut menunjukkan bahwa terdapat perbedaan pada hasil belajar siswa setelah menggunakan model group investigation berbantu media puzzle board dalam kegiatan belajar mengajar yang telah dilakukan. Dapat disimpulkan bahwa model pembelajaran group investigation berbantu media puzzle board efektif terhadap hasil belajar siswa.

\section{Pembahasan}

Berdasarkan hasil penelitian yang dilakukan menunjukkan bahwa terdapat perbedaan pada hasil belajar siswa setelah menggunakan model group investigation berbantu media puzzle board dalam kegiatan belajar mengajar yang telah dilakukan. Dapat disimpulkan bahwa model pembelajaran group investigation berbantu media puzzle board efektif terhadap hasil belajar siswa.

Model pembelajaran group investigation merupakan suatu pola pembelajaran yang memberikan kebebasan siswa untuk mengembangkan cara berfikir dan meningkatkan kemampuannya dengan menggali sumber belajar melalui kegiatan investigasi kelompok (Mushoddik et al., 2016; Suputra et al., 2013). Menurut Rusman (2017) strategi belajar koopratif group investigation sangat ideal diterapkan dalam pembelajaran biologi (IPA) hal ini dikarenakan topik pembelajaran IPA cukup luas dan sub bab topik yang mengarah pada kegiatan ilmiah. Selanjutnya dalam tahap investigasi siswa diarahkan untuk mencari tahu dari berbagai macam sumber. Siswa kemudian melakukan evaluasi dan sintesis terhadap informasi yang dihadapatkannya dalam upaya untuk membuat laporan ilmiah sebagai hasil kelompok. Media puzzle board merupakan media edukasi dua dimensi beralas papan dengan berbahan lembaran logam yang dapat menarik benda dengan daya magnet. Benda tersebut berupa potongan-potongan puzzle dengan bentuk alat pencernaan manusia yang dapat menempel atau merekat pada papan. Potongan-potongan puzzle dibuat menggunakan sterofom yang dilapisi kertas tebal berwarna-warni. Potongan puzzle dapat disusun atau ditempelkan pada papan dan membentuk keseluruhan secara utuh. Media puzzle board berfungsi sebagai alat bantu dalam 
memahami konsep pada materi alat pencernaan manusia secara berurutan (Dara Asshofi et al., 2019). Media ini memiliki daya tarik tersendiri, karena siswa dapat melihat secara langsung dan dengan leluasa memanipulasinya sesuai dengan materi pembelajaran. Melalui media puzzle board dapat meningkatkan antusias belajar dan kreativitas siswa. Model pembelajaran group investigation berbantu media puzzle board bisa memberi stimulasi belajar kepada siswa untuk aktif dalam kegiatan pembelajaran, sehingga dapat menciptakan pembelajaran yang efektif dalam situasi yang kondusif dan mampu meningkatkan hasil belajar siswa khususnya pada mata pelajaran IPA.

\section{Conclusion}

Berdasarkan hasil penelitian yang telah dilakukan dapat disimpulkan bahwa model pembelajaran group investigation berbantu media puzzle board efektif terhadap hasil belajar IPA pada materi alat pencernaan manusia siswa kelas V SDN Menur Demak. Dibuktikan dengan hasil analisis uji hipotesis menggunakan uji t dimana diperoleh $t_{\text {hitung }}$ sebesar 6,723 dan koefisien signifikansi pada taraf 5\% atau 0,05 dan d.b=22-1 maka diperoleh $t_{\text {tabel }}$ sebesar 2,080. Dari hasil analisis tersebut menunjukkan bahwa $t_{\text {hitung }}>\mathrm{t}_{\text {tabel }}(6,723>2,080)$, maka $\mathrm{H}_{0}$ ditolak dan $\mathrm{H}_{\mathrm{a}}$ diterima. Artinya, pmbelajaran dengan model group investigation berbantu media puzzle board efektif terhadap hasil belajar siswa.

Selain itu dibuktikan dengan hasil belajar siswa yang mengalami peningkatan yang dapat dilihat dari hasil nilai posttest lebih tinggi dari nilai pretest. Nilai rata-rata pretest yang telah dilakukan diperoleh sebesar 60,5 dan rata-rata posttest sebesar 72,5. Jika diubah dalam bentuk presentase jumlah siswa yang mencapai KKM pada hasil belajar pretest sebesar $22,7 \%$ sedangkan hasil posttest sebesar $86,36 \%$.

\section{References}

Azizah, A. (2018). Penerapan Model Pembelajaran Inkuiri Untuk Meningkatkan Hasil Belajar Ipa Siswa Kelas V Sekolah Dasar. Primary: Jurnal Pendidikan Guru Sekolah Dasar, 7(1), 106. https://doi.org/ 10.33578/jpfkip.v7i1.5358

Dara Asshofi, M. P., Damayani, A. T., \& . R. (2019). Peningkatan Hasil Belajar Matematika Materi Faktor Persekutuan Besar dan Kelipatan Persekutuan Kecil melalui Model NHT Berbantu Media Papan Puzzle Berbintang. Jurnal Ilmiah Sekolah Dasar, 3(4), 521. https://doi.org/10.23887/ jisd.v3i4.21881

Ernawati M, E. M. (2018). Penggunaan Metode Pendekatan Ketrampilan Proses Untuk Meningkatkan Aktivitas Hasil Belajar Ipa Siswa Kelas Iii Sekolah Dasar. Primary: Jurnal Pendidikan Guru Sekolah Dasar, 7(1), 75. https://doi.org/10.33578/jpfkip.v7i1.5350

Hayes, C., Hardian, H., \& Sumekar, T. (2017). Pengaruh Brain Training Terhadap Tingkat Inteligensia Pada Kelompok Usia Dewasa Muda. Diponegoro Medical Journal (Jurnal Kedokteran Diponegoro), 6(2), 402-416.

Mahnun, N. (2012). Media Pembelajaran (Kajian terhadap Langkah-langkah Pemilihan Media dan Implementasinya dalam Pembelajaran). An-Nida', 37(1), 27-35.

Maya, R. (2013). Esensi Guru dalam Visi-Misi Pendidikan Karakter. Edukasi Islami : Jurnal Pendidikan Islam, 2(3), 281-296. https://doi.org/ 10.30868/ei.v2i03.31

Mushoddik, Utaya, S., \& Budijanto. (2016). Pengaruh Model Pembelaaran Group Investigation Terhadap Kemampuan Berpikir Kritis Siswa MAN 6 Jakarta. Geo Edukasi, 5(2), 1-10. http://jurnalnasional.ump.ac.id/index.php/GeoEdukasi/index 
Purnamasari, U. A., Arifuddin, M., \& Hartini, S. (2018). Meningkatkan Aktivitas Belajar Siswa Pada Mata Pelajaran IPA Dengan Model Pembelajaran Kooperatif Tipe Group $\begin{array}{lllll}\text { Investigation. Berkala Ilmiah Pendidikan Fisika, } & 6(1), \quad .\end{array}$ https://doi.org/10.20527/bipf.v6i1.4471

Rusman. (2017). Model-Model Pembelajaran Mengembangkan Profesionalisme Guru Edisi Kedua. PT Grafindo Persada.

Samatowa, U. (2011). Pembelajaran IPA di Sekolah Dasar. Indeks.

Sudjana \& Rivai. (2010). Media Pengajaran. Sinar Baru Algensindo.

Sugiyono. (2016). Metode Penelitian Pendidikan (Pendekatan Kuantitatif, Kualitatif, dan $R \& D)$. Alfabeta.

Sulistiodiono. (2017). Model Pembelajaran Group Investigation (GI). 2, 312-318. http://jurnal.unublitar.ac.id/index.php/briliant

Suputra, W., Sedanayasa, G., \& Dibia, I. K. (2013). Pengaruh Model GI (Group Investigation) Berorientasi Kearifan Lokal Terhadap Kemampuan Berpikir Kritis SD Negeri Di Desa Sinabun. MIMBAR PGSD Undiksha, 1(1).

Susanto, A. (2016). Teori Belajar \& Pembelajaran di Sekolah Dasar. Paramedia.

Tias, I. W. U. (2017). Penerapan Model Penemuan Terbimbing Untuk Meningkatkan Hasil Belajar Ipa Siswa Sekolah Dasar. DWIJA CENDEKIA: Jurnal Riset Pedagogik, 1(1), 5060. https://doi.org/ 10.20961/jdc.v1i1.13060

Trianto. (2010). Model Pembelajaran Terpadu dalam Teori dan Praktek. Tim Prestasi Pustaka.

Wahyuni, S. (2014). Peningkatan Keaktifan Dan Hasil Belajar Ips Melalui Model Group Investigation (GI) Pada Siswa Kelas VI SDN Bandung, Wonosegoro. Scholaria : Jurnal $\begin{array}{llll}\text { Pendidikan Dan } & \text { Kebudayaan, }\end{array}$ https://doi.org/10.24246/j.scholaria.2014.v4.i3.p97-106

Wibowo, N. (2016). Upaya Peningkatan Keaktifan Siswa Melalui Pembelajaran Berdasarkan Gaya Belajar Di Smk Negeri 1 Saptosari. Elinvo (Electronics, Informatics, and Vocational Education), 1(2), 128-139. https://doi.org/10.21831/elinvo.v1i2.10621 